Vol. 2, No. 3, pp. 95-99, 2021

\title{
Socialization of Land Kangkung (Jpomoea Reptans Poir) Cultivation in Cibungur Village, Tasikmalaya, Indonesia
}

\author{
Fahmi Sidiq \\ Department of Pharmacy, Universitas Perjuangan, Tasikmalaya, Indonesia \\ Corresponding author email: fahmisidiq78@gmail.com
}

\begin{abstract}
The cultivation technique of land kangkung (Ipomoea reptana Poir) which is practiced by farmers is a non-machine technique. Farmers' cultivation techniques are tillage, seed dispersal, fertilization and harvesting at 40 days after planting. The purpose of this study was to determine the internal and external factors that influence the development of organic kale farming, and to determine the appropriate development strategy for organic kale farming. Data collection methods used are interviews, observation and literature study. The results of this study indicate that the internal strength factor in the development of organic kale farming is the availability of adequate organic fertilizer, while the weakness is the weakness of the product produced cannot meet consumer needs and organic labels. The external factor is the opportunity for organic kale to be marketed online, while the threat is the sale of more and more non-organic vegetables at lower prices.
\end{abstract}

Keywords: Strategy, development, farming, organic

\section{Introduction}

Community empowerment is an effort to increase the ability and potential of the community, so that the community can realize their identity, dignity and worth to the fullest in order to survive and develop themselves independently in the economic, social, religious and cultural fields (Swift and Levin, 1987; Umanailo, 2019).

Agriculture is one of the important sectors in development in Indonesia to date. Although Indonesia is an agricultural country, most of the farmers are small farmers (Schreer and Padmanabhan, 2020; David, 2017; Syuaib, 2016). Farmers belonging to this group usually only have limited agricultural land and not large enough capital. Kangkung is a plant that has considerable social and economic potential in the diversity of nutritious food. Water spinach is a source of nutrition that has a price and is easy to obtain (Situmeang and Suarta, 2018).

Organic Vegetables are vegetables that are cultivated naturally, the fertilizer given to vegetables comes from organic fertilizers, such as compost or manure so that opportunities and marketing increase. Promotional factors and location have a positive but not significant effect on purchasing decisions for organic vegetables (Pieniak et al., 2010). However, in running an organic water spinach farming business, there are various kinds of obstacles such as the need for capital in developing organic kale farming, the lack of production inputs, and the application of post-harvest technology is still weak.

According to Hasanah et al. (2020), water spinach plants consist of two varieties, namely land spinach or Chinese kale (Ipomoea reptans Poir) and water spinach (Ipomoea aquatica Forsk) which grow naturally in rice fields, swamps, or ditches. The difference between land kale and water spinach lies in the color of the flowers and the shape of the stems and leaves. Water spinach has reddish white flowers, the stems and leaves are larger, the color of the stem is green, while the land water spinach has long leaves with a whitish green pointed tip, the flowers are white.

Kangkung land (Ipomea reptans Poir) is one type of vegetable that is very popular for the people of Indonesia and much favored by all levels of society, because of its savory taste. Kale is a group of seasonal vegetable crops, shortlived and does not require a large area to cultivate it, making it possible to cultivate it in urban areas which generally have limited land for gardens. In addition to the savory taste, the nutrients contained in kale are quite high, such as vitamins $\mathrm{A}, \mathrm{B}$ and $\mathrm{C}$ as well as various minerals, especially iron, which are useful for body growth and health (Fidrianny et al., 2018).

This vegetable can grow well in the yard of the house, as well as in rice fields. Kangkung can also live well in the highlands and lowlands so that in almost all of our homeland this plant can be cultivated (Bennington and Habir, 
2003). In addition, land kale plants can be planted in areas with hot and humid climates, and grows well on soils rich in organic matter and sufficient nutrients, so that kale cultivation requires fertilizer to optimize growth and yields.

The cultivation of kale that is applied among farmers includes kale with conventional farming systems and organic systems. One of the advantages of kale grown with an organic system is the balance of the agroecosystem (Musyoka et al., 2019; Canwat et al., 2021). The advantage of the organic system is that it does not use chemical fertilizers or pesticides so that it does not cause environmental pollution, both soil, water and air pollution, and the products do not contain toxins. In addition, organic plants have a sweeter taste than non-organic plants (Harker, 2004). Therefore, it is necessary to conduct research on the comparison of the diversity of endophytic fungi on the leaves of land spinach cultivated on organic and conventional agricultural land. Thus, information is obtained that supports the application of an organic system and becomes a motivation for land kangkung farmers to apply land kangkung cultivation with an organic system (Seminar et al., 2017).

Organic fertilizers can improve and maintain soil fertility. In its application, organic fertilizers are generally given through the soil but can also be given through the leaves (Ayoola and Makinde, 2009). Another advantage of organic fertilizers is its ability to restore ecosystem balance, increase nutrient availability, stimulate plant root growth, biological control agents and increase profits in farming (Power, 2010; Tahat et al., 2020).

\section{Methodology}

The implementation of this service activity will take place on May 24, 2021 in Panagan Village (see Figure 1), Cibungur Village, District. Parungponteng, Regency. Tasikmalaya, West Java 46151.

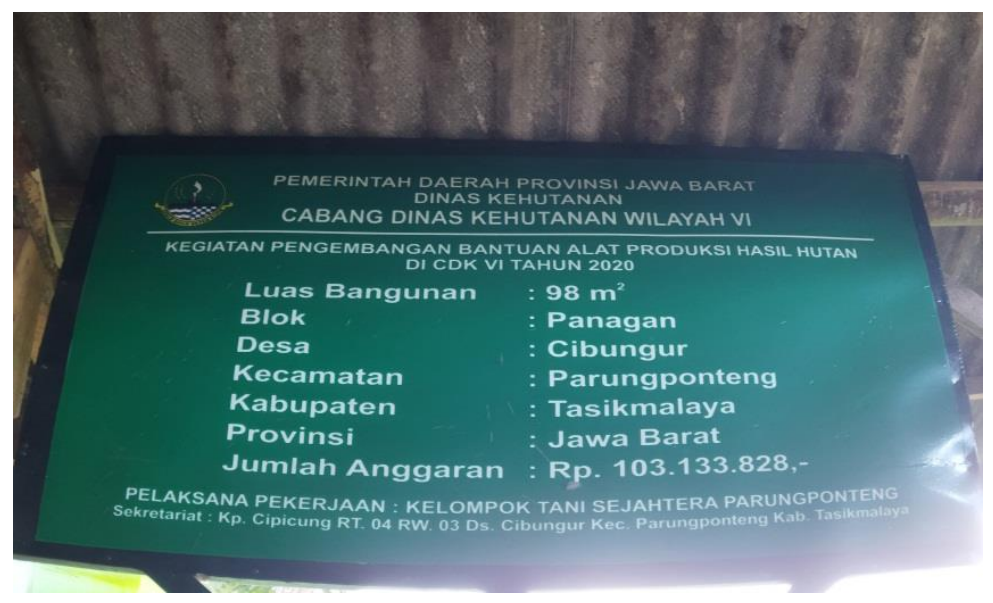

Figure 1. Parungponteng farmer group signpost

The methods used in the implementation of community service activities are field analysis, socialization of activities, and training which include:

\section{a. Observation}

Conducted interviews with the head of the Parungponteng Farmer Group located in Cibungur Village, Parungponteng District, Tasikmalaya Regency. With the consideration that in Cibungur village there are farmer groups that grow organic kale. Determination of respondents was carried out using the census method, namely all members of the Parungponteng farmer group were taken as many as 12 people as samples.

\section{b. Socialization Stage}

In this stage, the service team will provide and explain the service plan that will be carried out so that time and various technical needs can be arranged in connection with the overall implementation of the training.

\section{c. Training}

Socialization training on the procedures for cultivating kale, starting from the Nursery Requirements for Land Kangkung Seedlings The selection of seeds must be adjusted to the land (water or land). Because if land kale is planted on land for water spinach, the production is not good, the leaves turn yellow, are small and rot quickly. Processing of Planting Media by Formation of Beds The formation of beds for kale plants can be done with a width of 0.8-1.2 m, a length of 3-5 m, a depth of $\pm 15-20 \mathrm{~cm}$ and a distance between beds of $50 \mathrm{~cm}$ by making ditches. Making planting holes making planting holes can be done by hoe, which is $20 \times 20 \mathrm{~cm}$, as deep as $\pm 5 \mathrm{~cm}$. How to Planting 
Land kale planting is done in the afternoon from 16.00 to 18.00. plant maintenance includes fertilizing and watering harvesting

\section{Results And Discussion}

This Community Service (PKM) activity was carried out in Cibungur village, Parungponteng sub-district, Tasikmalaya, West Java 4615. This training method aims to provide knowledge about kale cultivation so that it becomes more advanced and produces quality (See Figure 2). So they can compete with other competitors.

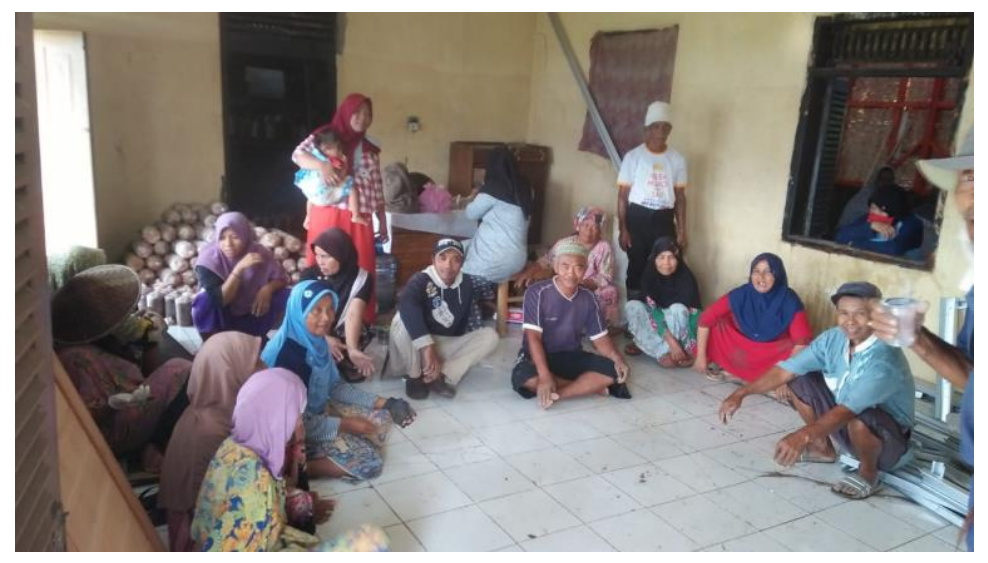

Figure 2. Water spinach plant socialization in the Parungponteng farmer group

Extension of optimal land use intensification is a model carried out by universities to utilize and optimize land use. The enthusiasm of the residents can be seen from the number of farmers who attended and the reciprocity in the discussion process during the meeting. The university's appeal and the hopes of farmers to make their kale vegetable cultivation more advanced with this activity.

From the results of interviews with farmer groups, it can be concluded that internal factors and external factors that occur in the Parungponteng farmer group, internal factors have the strengths of the Parungponteng Farmer Group, namely:

a. The resulting product is organic kale.

b. Existing land is fenced and has a water source (bore well).

c. Availability of adequate organic fertilizers.

The Weaknesses that exist in the Tapin Paku Farmer Group are: through direct interviews conducted with the head of the Parungponteng Farmers Group and Agricultural Extension Officers in the Parungponteng Farmers Group. From the results of interviews conducted, obtained eight internal factors (weaknesses) that affect the current business.

1. The resulting product does not meet consumer demand.

2. The business that is run is still on a family scale, due to little capital and small planting area.

3. There is no promotion of organic kale.

And as for external factors in the Parungponteng farmer group, there are opportunities:

1. Have few competitors because the products sold are organic products.

2. There is a modern market that sells organic products.

3. Consumer demand for organic products in the Tapin Paku Farmers Group is quite high.

The threats faced by the Parungponteng farmer group are:

1. Many farmers are starting to run organic farming systems.

2. Many plants are damaged when attacked by pests and diseases.

3. More and more sales of non-organic vegetables at lower prices.

4. Poor road transportation infrastructure and facilities.

This service will provide several activities to overcome what are the problems in planting kale by providing training and assistance. This training is related to how to cultivate kale, including how to select kale seeds, planting, maintenance and harvesting. future stages will be better. 


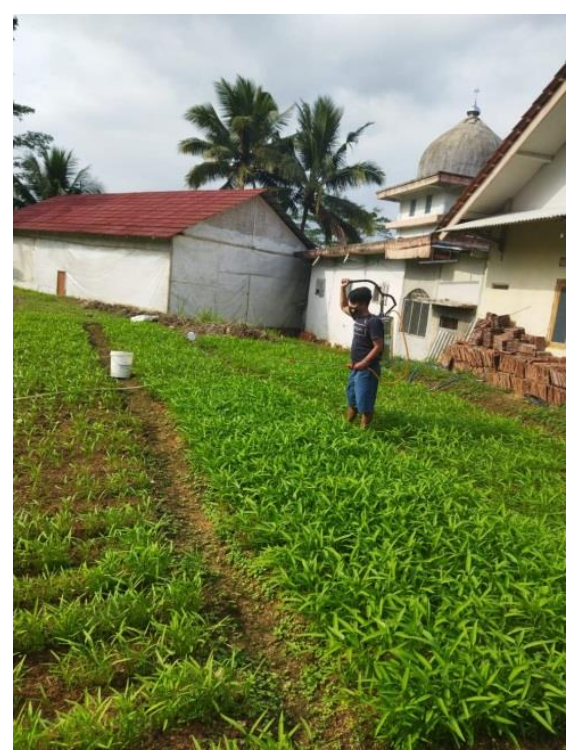

Figure 3. spraying organic fertilizer

The treatment process is important after the selection process for seeds and planting media, this process includes watering and fertilizing (See Figure 3). The fertilizer used is organic vegetable fertilizer (compost) which comes from household waste such as vegetable and fruit residues which are generally available in households. The application of fertilizer can be done in two stages, the first is that the application of urea fertilizer during the kale seeding period cannot be done. This is because at the time of seeding the kale, it is enough to give manure or compost as much as 2 to $3 \mathrm{~kg}$ of fertilizer for one square meter of kale. Second, the application of urea fertilizer during the basic growth of kale can be done with a combination of organic and inorganic fertilizers. You can add urea fertilizer for kale at this time at a dose of $75 \mathrm{~kg}$ of urea per hectare of kale.

You can add urea 10 days after planting at a dose of $50 \mathrm{~kg}$ of urea per hectare of kale. Urea fertilizer can be added again 20 days after planting with a dose of $15 \mathrm{~kg}$ of urea fertilizer per hectare of kangkung planting area. After that, the last application of urea fertilizer, which is 30 days after planting, urea fertilizer can be given at a dose of $15 \mathrm{~kg}$ of urea per hectare of kale planting area (see Figure 4).

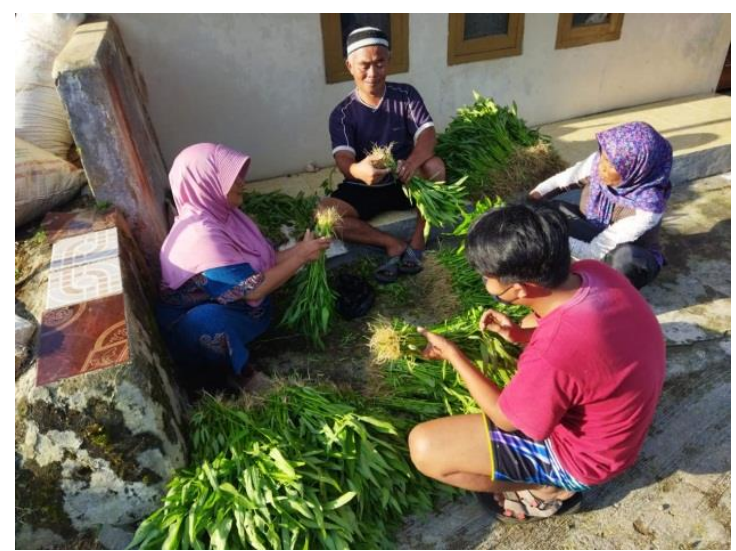

Figure 4. The process of harvesting kale with the head of the Parungponteng farmer group

Harvesting is done in the afternoon. Harvesting is done by cutting kale that is ready to harvest with the characteristics of large stems and broad leaves. By using a cutting tool. Harvesting is done every 2-3 weeks. Every time after harvest, usually new branches will be formed. After 5 harvests or 10-11 harvests, kale production will decrease both quantitatively and qualitatively. And Weaknesses post-harvest and low branding, Land processing is still manual using a hoe and crowbar, Determination of organic kale prices is still low, small-scale farming, Lack of product promotion efforts.

\section{Conclussion}

Kale is a group of seasonal vegetable crops, short-lived and does not require a large area to cultivate it, making it possible to cultivate it in urban areas which generally have limited land for gardens. In addition to its delicious taste, the nutrients contained in kale vegetables are quite high, such as vitamins A, B and C as well as various minerals, especially iron which is useful for body growth and health. Based on the results of the analysis of external and internal 
factors, it is known the factors that become strengths, weaknesses, opportunities and threats. The strength of the Parungponten group is that the product produced is organic kale, own land, The source of water for organic kale farming comes from drilled wells, and the Parungponteng group is used as a place for training and counseling. Weaknesses owned by farmer groups are post-harvest and low branding, Land processing is still manual using a hoe and crowbar, organic kale prices are still low, small-scale farming, and lack of product promotion efforts. Fertilization of kale is done twice organically, the first is the application of urea fertilizer at the time of seeding kale. secondly Provision of urea fertilizer during the basic growth of kale.

\section{References}

Ayoola, O. T., \& Makinde, E. (2009). Maize growth, yield and soil nutrient changes with N-enriched organic fertilizers. African Journal of food, agriculture, nutrition and development, 9(1), 580-592.

Bennington, L., \& Habir, A. D. (2003). Human resource management in Indonesia. Human Resource Management Review, 13(3), 373-392.

Canwat, V., Oelofse, M., Onakuse, S., \& de Neergaard, A. (2021). Agroecological intensification: Can organic conversion improve the production efficiency? A perspective from smallholder kale production systems Kenya. Cleaner Environmental Systems, 3, 100048 .

David, W. (2017). Organic agriculture in Indonesia: challenges and opportunities. Organic Agriculture, 7(3), 329-338.

Fidrianny, I., Suhendy, H., \& Insanu, M. (2018). Correlation of phytochemical content with antioxidant potential of various sweet potato (Ipomoea batatas) in West Java, Indonesia. Asian Pacific Journal of Tropical Biomedicine, 8(1), 25-38.

Harker, F. R. (2004). Organic food claims cannot be substantiated through testing of samples intercepted in the marketplace: a horticulturalist's opinion. Food Quality and Preference, 15(2), 91-95.

Hasanah, H., Achmadi, J., Pangestu, E., \& Agus, A. (2020). Supply Production of Water Spinach Waste as a Supplement and Fermentability Feed Ruminant in Klaten District, Indonesia (Case Study at Dry Season 2018). Journal of Computational and Theoretical Nanoscience, 17(2-3), 1196-1202.

Musyoka, M. W., Adamtey, N., Muriuki, A. W., Bautze, D., Karanja, E. N., Mucheru-Muna, M., \& Cadisch, G. (2019). Nitrogen leaching losses and balances in conventional and organic farming systems in Kenya. Nutrient Cycling in Agroecosystems, 114(3), 237-260.

Pieniak, Z., Aertsens, J., \& Verbeke, W. (2010). Subjective and objective knowledge as determinants of organic vegetables consumption. Food quality and preference, 21(6), 581-588.

Power, A. G. (2010). Ecosystem services and agriculture: tradeoffs and synergies. Philosophical transactions of the royal society B: biological sciences, 365(1554), 2959-2971.

Schreer, V., \& Padmanabhan, M. (2020). The many meanings of organic farming: Framing food security and food sovereignty in Indonesia. Organic Agriculture, 10(3), 327-338.

Seminar, A. U., Sarwoprasodjo, S., Santosa, D. A., \& Kinseng, R. A. (2017). Agroecological education aimed at achieving food sovereignty. Journal of Developments in Sustainable Agriculture, 12(1), 34-44.

Situmeang, Y. P., \& Suarta, M. (2018). The Effect of Biochar Bamboo on Growth and Results of Kangkung (Ipomoea Reptans P.). Journal of Biological and Chemical Research, 35(2), 463-468.

Swift, C., \& Levin, G. (1987). Empowerment: An emerging mental health technology. Journal of primary prevention, 8(1), 7194.

Syuaib, M. F. (2016). Sustainable agriculture in Indonesia: Facts and challenges to keep growing in harmony with environment. Agricultural Engineering International: CIGR Journal, 18(2), 170-184.

M Tahat, M., M Alananbeh, K., A Othman, Y., \& I Leskovar, D. (2020). Soil health and sustainable agriculture. Sustainability, 12(12), 4859.

Umanailo, M. C. B. (2019). Integration of Community Empowerment Models [Pengintegrasian Model Pemberdayaan Masyarakat]. Proceeding of Community Development, 2, 268-277. 